Discussion Paper No. 602

TESTING THE MORALE THEORY OF NOMINAL WAGE RIGIDITY

Daiji Kawaguchi and Fumio Ohtake

April 2004

The Institute of Social and Economic Research Osaka University

6-1 Mihogaoka, Ibaraki, Osaka 567-0047, Japan 


\title{
Testing the Morale Theory of Nominal Wage Rigidity
}

\author{
Daiji Kawaguchi \\ Graduate School of Humanities and Social Sciences \\ University of Tsukuba \\ and \\ Fumio Ohtake ${ }^{1} 2$ \\ Institute of Social and Economic Research \\ Osaka University
}

April 2004

\footnotetext{
${ }^{1}$ Corresponding Author; Address: Mihogaoka 6-1, Ibaraki, Osaka 567-0047, Japan; Tel: (81)-6-6879-8572; Fax: (81)-6-6878-2766; E-Mail: ohtake@iser.osakau.ac.jp

${ }^{2}$ We would like to thank Souichi Ohta and the participants of the 2003 Japan Economics Association annual meeting for their helpful comments. The remaining errors are, of course, our responsibility. We gratefully acknowledge the financial support from Suntory foundation, Grant-in-aid for scientific research (grant number (B)(2)12124207 and (C)(2)14530109), and the 21st century COE program (Osaka University).
} 


\begin{abstract}
This paper attempts to test the morale theory of nominal wage rigidity by identifying the causal effect of pay cuts on workers' income satisfaction and work morale. This paper uses the current deflationary recession in Japan to estimate this causal effect. Our original survey of Japanese firms and their employees conducted in 2000 revealed that about 17 percent of our sample experienced a nominal, annual income decline. These wage cuts severely decreased income satisfaction and work morale. We consider several channels through which pay cuts deteriorate workers' pay satisfaction and work morale. We found that an income freeze demoralizes workers by reducing workers' trust in their firms, but an income decline decreases work morale even after controlling for this reduction of trust. Allowing for the firm fixed effects does not alter the robust relationship between the income cut and demoralization. Overall, our results consistently indicate the adverse effect of income cuts on workers' pay satisfaction and morale. This evidence, obtained from a deflationary economy, supports Bewley (1999)'s morale theory of nominal wage rigidity.
\end{abstract}




\section{Introduction}

This paper tests the morale theory of nominal wage rigidity proposed by Bewley (1999), using an original employer-employee survey conducted in the middle of Japan's ongoing deflationary recession. Downward nominal wage rigidity has attracted economists' interest, mainly due to its important implications for monetary policy. Recent studies based on panel data of workers have indicated that there is a significant degree of downward nominal wage rigidity. For example, McLaughlin (1994), Kahn (1997), Card and Hyslop (1997), Altonji and Devereux (2000) and McLaughlin (2000) examined US micro data to find the existence and degree of nominal downward wage rigidity. Smith (2000) examined British micro data and Kuroda and Yamamoto (2003a) and Kuroda and Yamamoto (2003b) examined Japanese micro data. ${ }^{1}$ All of these studies have examined the distribution of nominal wage change using panel data and have found an asymmetric distribution skewed to the right, with a sharp spike at no nominal wage change. The observed distributions are consistent with the existence of downward nominal wage rigidity. Few of the studies mentioned above have investigated the reasons why nominal wages do not fall, mainly because the data used did not contain enough information on the workers' workplace and the workers' emotional reactions to wage cuts.

The reasons for downward nominal wage rigidity have been mainly in-

\footnotetext{
${ }^{1}$ Based on the observed downward nominal wage rigidity among Japanese youth, Kondo (2003) considered the reasons why their wage is particularly downwardly rigid.
} 
vestigated through interviews with employers, asking the reasons why they do not cut wages, even during a recession. Bewley (1999) interviewed more than 300 business executives and labor leaders in the Northeastern region of the US during the recession of the early 1990s and found that employers avoided pay cuts because they expected that pay cuts would demoralize workers and reduce workers' effort. Similar findings have been reported in Kaufman (1984) and Blinder and Choi (1990) based on smaller-scale employer interviews. Another line of research by Loewenstein and Sicherman (1991) and Frank and Hutchens (1993) offered evidence that workers prefer an increasing wage profile, and in particular, Loewenstein and Sicherman (1991) introduced the popular survey responses that workers perceive wage cuts as a sign that their employers do not appreciate their efforts. This evidence indirectly established the link between wage cuts and workers' morale. Few studies, however, have attempted to establish the direct, causal relationship between wage cuts and workers' morale using a sample of workers who actually experienced wage cuts. An exceptional study is that of Smith (2002), who examined the relationship between wage cuts and workers' satisfaction with their wages. She used the British Household Panel Study to examine the effect of wage cuts and freezes on workers' self-reported satisfaction with their pay. She found that both wage cuts and freezes negatively affect workers' satisfaction with their pay by almost the same degree. Because the inflation rate was about 8 to 9 percent at the beginning of the 1990s and was about 2 to 3 percent after 1993, the nominal wage freeze in 
the 1990s in the UK implied a real wage cut. From the finding that wage freezes and cuts affect workers' pay satisfaction in a similar fashion, Smith (2002) concluded that workers' pay satisfaction is deteriorated by real wage cuts rather than by nominal wage cuts.

The morale theory of nominal wage rigidity is powerfully tested in a deflationary economy. Under inflation, nominal wage freezes imply real wage cuts and distinguishing the effects of a nominal wage freeze and a nominal wage decrease on workers' morale is impossible if workers care about real wages. At the same time, a nominal wage freeze implies a real wage increase under deflation, and it is still possible to identify the effect of a nominal wage decrease on workers' morale, even if workers react to real change given the degree of the nominal wage decline dominates the degree of deflation. In this sense, we can test the effect of nominal wage decline on workers' morale without identifying whether workers are reacting to real or nominal changes in a deflationary economy. In other words, using data on income change and work morale from a deflationary economy, we can identify the reduced-form relationship between nominal wage decline and work morale that we wish to address.

The discussion above indicates the importance of examining the effects of nominal wage cuts on workers' pay satisfaction or morale during a deflationary recession; however, the actual analysis has not been easy because the occurrence of actual deflation has been quite rare. In this sense, the current deflation in Japan offers an ideal ground for testing the morale theory of wage 
rigidity by Bewley (1999). As evidenced in Figure 1, Japan has experienced a general price decline since the beginning of 1998, and this trend continued until at least the end of $2001 .^{2}$ We use an original employer - employee survey conducted in July 2000 in Japan to examine how workers' pay satisfaction and work morale are affected by nominal wage cuts/freezes.

The rest of this paper is organized as follows. Section 2 describes the data used in this study. Section 3 analyzes the frequency of wage declines and freezes and who experienced them. Section 4 analyzes the effect of wage declines and freezes on workers' satisfaction with their earnings. The last section concludes.

\section{Data}

The Institute of Industrial and Labor Policies, Chubu (Chubu Sansei Ken in Japanese) conducted a survey covering 123 companies and their employees in the Chubu area of Japan, which is the area around Nagoya including Toyota: a well-known motor town. The companies include Toyota and its subsidiary parts suppliers, Chubu electric power, Matsuzakaya department store, Nagoya railway, and other companies.

The survey consists of a firm questionnaire and an employee questionnaire. Human resource departments were asked to complete the firm survey questionnaire. The employee survey questionnaires were distributed and col-

\footnotetext{
${ }^{2}$ An overview of the recent deflation in Japan is available in Ahearne, Gagnon, Haltmaier, and Kamin (2002).
} 
lected through labor unions in the case of unionized workers and through human resource departments in the case of non-unionized workers. The employee questionnaires were collected in sealed envelopes to obtain the employees' honest opinions and to guard their privacy. The questionnaires were distributed July 5-7, 2000 and were collected at the end of the same month. The Institute distributed 123 firm questionnaires and collected 83 of them; the response rate was $67.5 \%$. It randomly chose 2000 employees, distributed the questionnaires, and collected 1823 of them, for a response rate of $91.2 \%$.

The response rate was quite high for this type of survey, and the sample presumably represents the population: all employees of the 123 firms in this case. Among these observations, we dropped the female observations and restricted our sample to observations for which all of the following information was available: educational background, income, industry, occupation, and changes in basic pay, bonuses, and annual income. This sample restriction reduced the sample size to 1557 .

The descriptive statistics of the respondents appear in Table 1. The average age of workers was about 37 years old and the average tenure was about 17 years. As for educational background, the majority of the sample (51\%) was high school graduates and $29 \%$ of the whole sample was college graduates. Considering the distribution of years of education and age, the average job tenure was long, reflecting the long-term employment relationship typical in Japan, as articulated by Hart and Kawasaki (1999). More than half of the sample earned between 5000 and 7990 thousand yen annually (One 
dollar was traded for 105 - 110 yen in July 2000). The earnings distribution was skewed to the right, as in the usual earnings distribution. We also report the comparable national figures taken from Japan Institute of Labour (2002) in Column (2). Compared with these national average figures, workers in the analysis sample had longer job tenure and a higher educational background and enjoyed higher earnings. It is important to note that our sample basically is comprised of workers who are in "good jobs."

\section{Whose Wages Fall in Deflation?}

The employee survey asked about the changes in i) basic pay, ii) bonus pay, and iii) annual income from the previous year, and workers were asked to choose one of the following three options: a) decreased, b) frozen, or c) increased. The responses to this question by age categories appear in Table 2. It is striking that about $17 \%$ of the workers in the sample experienced an annual income decline. The distribution of changes shows that bonus pay was more likely to be frozen or decreased than basic pay, and this may reflect the fact that bonus pay is more vulnerable to a firm's performance. The age decomposition shows that basic pay/bonus decreases/freezes were more likely to occur among older workers, particularly workers between ages 50 and $59 .^{3}$

\footnotetext{
${ }^{3}$ The high frequency of basic pay decline among workers in this particular age group may be partly due to the "position-retirement" that is a widely observed employment custom in Japan. Since large firms in Japan tend to adopt up-or-out career systems during the late stage of workers' careers, those workers who are in administrative (white collar) or foreman (blue collar) positions but fail to be promoted to the higher position
} 
Among workers between ages 40 and 49, 6.45\% and $16.13 \%$ of workers experienced a basic pay and bonus decline respectively. In total, $18.43 \%$ of workers in this age range experienced annual income decline. The proportion of workers who experienced annual income decline was $14.02 \%$ among workers between ages 30 and 39 and $12.89 \%$ among workers between 20 and 30. A comparison of these percentages reveals that an annual income decline was more prevalent among older workers. In particular, the decrease in basic pay was relatively rare among workers between ages 20 and 30 compared with older workers.

To examine the effect of age on the probability of experiencing an annual income decline or freeze, holding educational background, income level, industry, and occupation constant, we estimate the multinomial logit model, in which the dependent variable is a categorical variable corresponding to annual income 3. declined, 2. frozen, and 1. increased. The results of the estimation appear in Table 3. The results of the estimation show that older workers are less likely to experience an annual income increase even after controlling for covariates, as reported in Column (1), but once the effects of covariates are controlled for, age does not explain the annual income decrease, as reported in Column (2). To check the appropriateness of the linear specification with respect to age and tenure, the specification that includes the squared term of age and tenure is estimated and the results are are asked to leave the company with some premium on their retirement allowance. If a worker prefers to stay in the firm, he is asked to retire from his current position and work in a lower one; a basic pay cut is usually associated with this transition. 
reported in Columns (3) and (4). Nonetheless, those two terms do not enter the equation significantly, and the linear specification is sufficient to capture the effect of age and tenure on annual income change. To conclude, after conditioning on the covariates, including income level, older workers are less likely to experience an annual income increase, but they are not more likely to experience income decrease. Thus we roughly conclude that workers in all age ranges are equally likely to experience a wage decrease conditioned on the covariates, including their current income level.

\section{The Effect of Wage Cuts on Workers' Sat- isfaction with Their Pay}

This section analyzes how income decreases and freezes affected workers' satisfaction with their pay. As a measure of workers' satisfaction with their wages, we analyzed responses to the following question: "Are you satisfied with your current annual income? Please answer using a percentage, where 100 percent means that you are completely satisfied with your annual income." We assume that the response to this question is determined by

$$
y_{i}=\beta_{1} \text { Increase }_{i}+\beta_{2} \text { Decrease }_{i}+x_{i} \gamma+u_{i},
$$

where $y_{i}$ is the worker $i$ 's satisfaction with his pay, Increase $_{i}$ and Decrease D $_{i}$ are the dummy variables that take one if the worker $i$ experienced an income increase and decrease respectively. The vector $x_{i}$ contains sets of covariates that can affect the workers' pay satisfaction and can be correlated with the 
event of a pay freeze or decline. Most importantly, $x_{i}$ contains income category dummy variables to control for the effect of income level on income satisfaction.

The results of the estimation controlling for education, income class, industry, and occupation appear in Column (1) of Table 4. An income increase boosts workers' satisfaction with their annual income by 8.04 percentage points while an income decrease diminishes the satisfaction by 3.13 percentage points, compared with the case of an income freeze.

Annual income decline may decrease workers' satisfaction with their pay through several channels. As Clark and Oswald (1996) discussed, relative income, rather than absolute income, determines workers' satisfaction. It may be relative income decline compared with a reference group, rather than income decline itself, that negatively affects workers' income satisfaction. To address this possibility, we used a question asking workers' perceived relative position of their annual income compared with colleagues of the same sex, age, educational background, occupation, etc. Workers were asked to answer this question with one of the following six response categories: 1. Upper (Above top $20 \%$ ), 2. Upper middle (from top 20\% to top 40\%), 3. Middle (top 40\% to top 60\%), 4. Lower middle (Bottom 20\% to bottom 40\%), 5 . Bottom (Below bottom 20\%) and 6. Do not know. The estimation results of the model that includes dummy variables for each of these categories appear in Column (2). This inclusion of relative income position dummy variables, however, does not essentially change the results from Column (1). 
If workers strongly attach to their firms by accumulating firm-specific human capital, they have good reason to care about their firms' growth. Firms' growth may affect workers' satisfaction with their wages because workers with poor future prospects may require higher current wages to compensate for their future lower expected wages. Income declines and freezes may be correlated with firms' growth, and the coefficient on the income decline or freeze dummy variables may be subject to omitted variable bias. To deal with this issue, we included firms' sales growth between 1996 and 1999 (budget year) and employment growth between 1997 and 2000 (calendar year) as proxy variables for firms' expected growth. The estimated results appear in Column (3) of Table 4. Although sales growth positively affected workers' income satisfaction, the coefficients for the income freeze or decline dummy variables and their interaction with the age dummy variables did not essentially differ from the results in Column (2).

According to Lazear's long-term contract theory (Lazear (1979) and Lazear (1981)), young workers are paid below their marginal product and old workers are paid above their marginal product to induce workers' effort when workers' effort is not perfectly observed by firms. As mentioned in Lazear's original work and formalized in Kanemoto and MacLeod (1992), this type of long-term contract depends strongly on the workers' trust that their firms will repay the difference of wage and productivity when workers get old. Thus, wage cuts may damage workers' trust in their firms and reduce their satisfaction with their pay. Alternatively, as Bewley (1999) discussed, wage 
cuts may directly destroy the workers' trust in their firms and reduce workers' satisfaction with their wages because workers no longer feel identified with their firms. Both theories predict that wage cuts will reduce workers' satisfaction with their wages via the reduction of their trust in their firms.

To evaluate these possibilities, we include several variables that presumably capture the transparency of each firm's wage- determining mechanism and workers' trust in their firms. The firm survey asked whether each firm publicized the following items to their workers: 1 . wage schedule, 2 . worker evaluation sheet, 3 . the standards for worker evaluation, 4 . the mechanism of wage and bonus determination based on worker evaluation, and 5 . the mechanism of promotion determination based on worker evaluation. The firms were allowed to choose one of the following three choices: 1. Yes, 2. No, 3. We do not have one. We created the dummy variable indicating "yes" to each question and included the dummy variables as explanatory variables in (1). These dummy variables are supposed to capture the trust between firms and workers created through the transparency of wage/bonus/promotion determination. In addition, answers for several questions in the employee survey were included as explanatory variables. The first item used was the answer to a question regarding whether an employee's trust had increased or decreased in these three years. Employees were asked to answer the question using the numbers between 1 (decreased very much) and 5 (increased very much). This index is directly included in the regression. The questions that asked workers their perceptions of the firm's fairness in promotion and wage 
determination were also used. One question asked whether the respondent felt that the firm's promotional decisions were fair, and the respondent could choose one of the following alternatives: 1. unfair, 2. rather unfair, 3. neither fair nor unfair, 4. rather fair, 5 fair. This response is directly introduced in the regression. The employee questionnaire also asked for each worker's subjective satisfaction with the firm's evaluation of his work performance. Each respondent was allowed to answer this question using a number between 0 and 100. This variable is also directly introduced in the regression. The other question that is intended to capture each worker's trust in his firm asks how workers express their work-related complaints. Respondents were allowed to choose one from the following answers:

1. consult the labor union at your workplace, 2. consult colleagues at your workplace, 3. consult a superior at your workplace, 4. tell people in the human resource division, 5. file complaint to complaint bureau at your workplace, 6. complete an opinion survey administrated by your company, 7. consult an external organization dealing with labor issues, 8. consult a lawyer, 9. do not tell anyone and try to be patient, 10. consider a job change, 11. rely on other methods (specify).

The dummy variables were created that take one if the respondent expressed his complaint through a labor union (i.e., the worker chose the alternative 1) and company (i.e., the worker chose at least one of the alternatives between 3 and 6). Both dummy variables are included in the regression to capture the worker's trust in his labor union and firm. 
The regression results, including all of the variables explained above that presumably capture each worker's trust in his firm, appear in Column (4) of Table 3. The coefficients for income increase boost workers' satisfaction by 4.53 percentage points, while income decline diminishes the satisfaction by 2.96 percentage points compared with the case of income freeze. Thus, the speculation that income decline decreases workers' income satisfaction by destroying the trust between workers and firms is not strongly supported by the data.

The results of a regression that includes both proxy variables representing each firm's growth and each worker's trust appear in Column (5) of Table 3. The results do not essentially change from the results reported in Column (4). Even after controlling for several factors, the negative effect of income decline on income satisfaction is robust and stronger among younger workers.

As confirmed in Tables 2 and 3, older workers are less likely to experience a wage increase. This could be so because the effect of an income freeze on pay satisfaction may differ depending on workers' age. To examine this possibility, a specification that includes the interaction terms between income increase or decrease dummy with age is estimated and the result is reported in Column (6). The coefficient for the interaction term of income increase and age is negative, which implies that an income increase brings less pay satisfaction among older workers. Otherwise, this result can be interpreted that younger workers' pay satisfaction is more strongly deteriorated by a pay freeze. This is probably because younger workers expect an income increase 
more strongly than older workers. An interesting result is the zero coefficient for the interaction term between income decrease and age. This result implies that an income decline negatively affects workers' pay satisfaction by the same degree, regardless of the workers' age.

Thus far, the analysis neglects the firms' heterogeneity, which could be correlated with the event of an income increase or decrease. Neglecting firms' heterogeneity could potentially bias the estimated coefficients for an income decrease. On the one hand, those firms that cut workers' income may be experiencing financial hardship that is not captured by observed variables. This financial hardship may create a bitter atmosphere among workers, which may negatively affect workers' pay satisfaction. Then the adverse effect of a pay cut on workers' pay satisfaction may operate through a worse workplace atmosphere. On the other hand, if firms attempt to keep the number of employment by adopting a pay cut, workers may react less negatively to the income cut. In this case, the negative effect of income cut on pay satisfaction is under-estimated because we failed to hold firms' employment policies constant. To deal with these possible biases, whose sign cannot be determined a priori, we adopt a firm-level fixed effects estimation. The result of the estimation appears in Column (7) of Table 4. The result is virtually identical to the result reported in Column (6), and the effect of the heterogeneity bias seems to be minimal. 


\section{The Effect of Wage Cuts on Workers' Work Motivation}

In this section, we attempt to directly recover the causal relationship between income change and the change of workers' morale. The employee survey asked about the change of the individual worker's and workplace morale in the past 3 years. The question reads "How has your individual and your workplace morale changed in the past 3 years?" and employees were asked to answer this question by choosing one of the following choices as a description for his own and workplace morale respectively; 1: Decreased, 2: Rather decreased, 3: Hard to tell, 4: Rather increased, 5: Increased. Using this question, we relate the change of income and the change of the individual workers' morale.

Using this question has two merits. First, the question directly asks about individual workers' morale and we can directly test the morale theory by Bewley (1999). Second, the question asks about the change of workers' morale instead of the level of workers' morale. Thus we can avoid the interpersonal comparison of a subjective answer. In addition, we can relate the change of income with the change of work morale. One drawback is that the income change question asked about the change over the previous year, but the morale change question asked about the change over the past three years.

The latent variable of the change of workers' morale is specified as:

$$
m_{i}^{*}=\beta_{1} \text { Increase }_{i}+\beta_{2} \text { Decrease }_{i}+x_{i} \gamma+u_{i},
$$


where all the notations except for $m_{i}^{*}$ are the same as for equation (1) while $m_{i}^{*}$ is the latent variable of the change of workers' morale. This latent variable is linked to the observed response by the following equation:

$$
m_{i}= \begin{cases}5 & \text { if } m_{i}^{*} \geq \mu_{4}, \\ 4 & \text { if } \mu_{4}>m_{i}^{*} \geq \mu_{3}, \\ 3 & \text { if } \mu_{3}>m_{i}^{*} \geq \mu_{2}, \\ 2 & \text { if } \mu_{2}>m_{i}^{*} \geq \mu_{1}, \\ 1 & \text { if } \mu_{1}>m_{i}^{*},\end{cases}
$$

where $m_{i}$ is a categorical variable indicating worker $i$ 's response to the morale question (1: "Decreased" - 5: "Increased") and $\mu_{k}(k=1,2,3,4)$ are the thresholds of morale change that determine the answer for the morale question. The result of the estimation with standard covariates appears in Column (1) of Table 5. The result indicates that income increase stimulates work morale, while income decrease demoralizes workers. Both effects are statistically significant.

The effect of income change on morale change can operate through several channels. To identify these channels, sets of covariates are added to the morale change equation gradually, as in the analysis of the previous section. The first set of covariates is the workers' perception of their relative income position and the result of the estimation appears in Column (2) of Table 5. The result is essentially identical to that of Column (1), except for the size of estimated coefficients. The second set of covariates is the proxy variables for the firms' growth: firms' sales growth between 1996 and 1999 and employment growth between 1997 and 2000. The result of the estimation is reported in Column (3), and the result does not differ drastically from that 
of Column (2). The third set of covariates is the proxy variables for workers' trust in their firms: transparency of firms' wage policy, workers' self-reported change in the trust toward their firm in the past three years, workers' perceived fairness of promotion and wage determination, and to whom workers' work-related complaints are directed. The inclusion of this set of covariates drastically changes the estimated effect of income change on the change of work morale, as reported in Column (4). Income increase no longer pushes up workers' morale after conditioning on workers' trust in their firms. This change of result implies that the positive effect of income increase on workers' morale operates by fostering workers' trust in their employers. To the contrary, the adverse effect of income cut on workers' morale is estimated to be significant even after controlling for the change in workers' trust in their employers. The results of the estimation that includes the proxy for firm growth in addition to the variables included in Column (4) appears in Column (5). The addition of the proxy variables for firm growth does not significantly change the estimation results.

Thus far, we have neglected the possible heterogeneous morale response to income change depending on the workers' age. To allow for this heterogeneity, the interaction term of age and dummy variables for income increase and decrease are introduced into the specification. The result of the estimation is reported in Column (6). The coefficients for the interaction terms are virtually zero and the morale responses are homogeneous across age groups. Lastly, we consider firms' unobserved heterogeneity that is potentially corre- 
lated with the event of income increase or decrease. The existence of correlated heterogeneity could bias the coefficient for income decrease, either in an upward or downward direction. The event of income decrease may be more likely to occur in the firms that attempt to keep the number of employees through pay cuts or in the firms that have a deteriorating workplace atmosphere. To address this possible heterogeneity bias, we introduced dummy variables for each firm in the estimation. The result of estimation appears in Column (7), and it is virtually unchanged from the result in Column (6).

The results reported in this section clearly indicate the negative effects of income cuts on workers' morale, even after controlling for several factors that could occur simultaneously with income change, such as a change in workers' trust in their employers or employers' unobserved heterogeneity. This result supports Bewley (1999)'s morale theory of nominal wage rigidity.

\section{Conclusion}

Using a firm-employee survey of Japan conducted in 2000, this paper examined the effect of pay cuts on workers' pay satisfaction and work morale under deflation. The data show that about 17 percent of workers experienced an annual, nominal income cut. Those workers who experienced income cuts were less satisfied with their pay and had lower work morale than those who did not experience an income cut. We found that an income increase positively affected workers' morale by fostering workers' trust in their firms. In contrast, even after controlling for the workers' trust in their firms, income 
cuts negatively affected workers' work morale. These findings are very robust, even after controlling for workers' and employers' heterogeneity by using the rich information available in our survey.

Our results clearly indicate that workers are demoralized by nominal income cuts, even during the deflation. The results obtained in this paper supports Bewley (1999)' morale theory of wage rigidity, although whether the wage cut was real or just nominal was indistinguishable because the exact amount of the nominal income cut was unknown in our survey. We offer strong evidence that nominal wage decreases demoralize workers, while wage freezes do not under deflation. This evidence explains why the nominal wage is rigid in a downward direction and the distribution of wage change has spike at zero even during a deflationary recession.

\section{References}

Ahearne, A. J. Gagnon J. Haltmaier and S. Kamin, 2002, Preventing Deflation: Lessons from Japan's Experience in the 1990s, Board of Governors of the Federal Reserve System, International Finance Discussion Papers No.729.

Altonji, J. G. and P. J. Devereux, 2000, The Extent and Consequences of Downward Nominal Wage Rigidity, Research in Labor Economics, 19.

Bewley, T. F., 1999, Why wages don't fall during a recession. Harvard University Press. 
Blinder, A. S. and D. H. Choi, 1990, A Shred of Evidence on Theories of Wage Stickiness, Quarterly Journal of Economics, 105(4), 1003-1015.

Card, D. and D. Hyslop, 1997, Does Inflation "Greese The Wheels of the Labor Market?", in Reducing Inflation: Motivation and Strategy, ed. by C. Romer and D. Romer, vol. 30. NBER.

Clark, A. E. and A. J. Oswald, 1996, Satisfaction and Comparison Income, Journal of Public Economics, 61(3), 359-381.

Frank, R. H. and R. M. Hutchens, 1993, Wages, Seniority, and the Demand for Rising Consumption Profiles, Journal of Economic Behaviour and Organization, 21(3), 251-276.

Hart, R. A. and S. Kawasaki, 1999, Work and Pay in Japan. Cambridge University Press.

Japan Institute of Labour, 2002, Japanese Working Life Profile. Japan Institute of Labour.

Kahn, S., 1997, Evidence of Nominal Wage Stickiness from Microdata, American Economic Review, 87(5), 993-1008.

Kanemoto, Y. and B. W. MacLeod, 1992, Firm Reputation and SelfEnforcing Labor Contracts, Journal of the Japanese and International Economies, 6(2), 144-162. 
Kaufman, R., 1984, On Wage Stickiness in Britain's Competitive Sector, British Journal of Industrial Relations, 22(101), 101-112.

Kondo, A., 2003, Nominal Wage Rigidity for Japanese Youth, The University of Tokyo.

Kuroda, S. and I. Yamamoto, 2003a, Is Wage in Japan Downwardly Rigid? Part I - Examination of the Distribution of Wage Change (in Japanese), Bank of Japan, IMES Discussion Paper No. 2003-J-2.

_ 2003b, Is Wage in Japan Downwardly Rigid? Part II - Estimation of the Friction Model (in Japanese), Bank of Japan, IMES Discussion Paper No. 2003-J-3.

Lazear, E. P., 1979, Why Is There Mandatory Retirement?, Journal of Political Economy, 87(6), 1261-1284.

— , 1981, Agency, Earnings Profiles, Productivity, and Hours Restrictions, American Economic Review, 71(4), 606-620.

Loewenstein, G. and N. Sicherman, 1991, Do Workers Prefer Increasing Wage Profiles?, Journal of Labor Economics, 9(1), 67-84.

McLaughlin, K. J., 1994, Rigid Wages?, Journal of Monetary Economics, $34(3), 383-414$.

— , 2000, Asymmetric Wage Changes and Downward Nominal Wage 
Rigidity, Unpublished Manuscript, Hunter College, City University of New York.

Smith, J. C., 2000, Nominal Wage Rigidity in the United Kingdom, Economic Journal, 110(462), C176-C195.

, 2002, Pay Cuts and Morale: A Test of Downward Nominal Rigidity,

Warwick Economic Research Papers No. 649. 
Table 1: Descriptive Statistics

\begin{tabular}{|c|c|c|}
\hline & (1) & (2) \\
\hline Variable & $\begin{array}{c}\text { Analysis } \\
\text { Sample }\end{array}$ & $\begin{array}{c}\text { National Figures for Male } \\
\text { Workers }\end{array}$ \\
\hline Age & $\begin{array}{l}37.49 \\
(7.34)\end{array}$ & 39.7 \\
\hline Tenure & $\begin{array}{l}16.99 \\
(7.92)\end{array}$ & 11.8 \\
\hline \multicolumn{3}{|l|}{ Education (Category Dummies) } \\
\hline Junior High School & 0.04 & 0.16 \\
\hline High School & 0.51 & 0.29 \\
\hline Technical College & 0.02 & \multirow{6}{*}{$\begin{array}{c}\text { \} } 0.08 \text { (Technical Coll. + } \\
\text { Junior Coll. }) \\
\text { \} } 0.29 \text { (College }+ \text { Graduate } \\
\text { School })\end{array}$} \\
\hline Tech. Coll. Attached to the Firm & 0.06 & \\
\hline Junior College & 0.02 & \\
\hline College (Humanities and Social Sciences) & 0.14 & \\
\hline College (Engineering and Natural Sciences) & 0.15 & \\
\hline Graduate School & 0.06 & \\
\hline \multicolumn{3}{|c|}{ Annual Income (10 Thousand Yen) (Category Dummies) } \\
\hline-299 & 0.01 & Average Annual Income \\
\hline $300-399$ & 0.05 & (10 Thousand Yen) \\
\hline $400-499$ & 0.14 & College Graduates \\
\hline $500-599$ & 0.17 & 522 \\
\hline $600-699$ & 0.17 & Tech. Coll. + Junior College \\
\hline $700-799$ & 0.17 & 382.8 \\
\hline $800-899$ & 0.11 & High School Graduates \\
\hline $900-999$ & 0.08 & 448.3 \\
\hline 1000-1099 & 0.05 & \\
\hline $1100-1199$ & 0.02 & \\
\hline $1200-1299$ & 0.01 & \\
\hline 1300-1399 & 0.01 & \\
\hline 1400-1499 & $<0.00$ & \\
\hline $1500-$ & $<0.00$ & \\
\hline $\mathrm{N}$ & 1557 & \\
\hline
\end{tabular}

Note: Age, education, and annual income are category variables. Means of the variables are reported and standard errors are reported in parentheses. All national figures are taken from the Japan Institute of Labour (2002). Average age and tenure of workers are based on Table 16 and figures are for 1999. The distribution for educational background is based on Table 15 that contains figures for 1997. Average annual income for each educational background is based on Table 38, which contains the amount of scheduled case earnings for 2000. We imputed annual income assuming that workers receive 4 months salary as a bonus in a given year. Receiving a bonus equivalent to 4 months salary is roughly consistent with the national figures reported in Table 37. 
Table 2: Descriptive Statistics of Wage or Income Decline (Employee Reported)

\begin{tabular}{|c|c|c|c|c|c|}
\hline Age Group & $<30$ & $30-39$ & $40-49$ & $50-59$ & Total \\
\hline \multicolumn{6}{|l|}{ Basic Pay } \\
\hline Decrease & 2.06 & 5.51 & 6.45 & 16.38 & 6.17 \\
\hline Freeze & 13.92 & 14.52 & 22.35 & 30.77 & 17.98 \\
\hline Increase & 84.02 & 79.97 & 71.20 & 53.85 & 75.85 \\
\hline \multicolumn{6}{|l|}{ Bonus } \\
\hline Decrease & 13.40 & 13.77 & 16.13 & 38.46 & 16.44 \\
\hline Freeze & 23.20 & 23.78 & 26.78 & 24.62 & 24.60 \\
\hline Increase & 63.40 & 62.45 & 57.14 & 36.92 & 58.96 \\
\hline \multicolumn{6}{|l|}{ Annual Income } \\
\hline Decrease & 12.89 & 14.02 & 18.43 & 30.77 & 16.51 \\
\hline Freeze & 17.53 & 19.52 & 23.27 & 28.46 & 21.07 \\
\hline Increase & 69.59 & 66.46 & 58.29 & 40.77 & 62.43 \\
\hline $\mathrm{N}$ & 194 & 799 & 434 & 130 & 1557 \\
\hline
\end{tabular}


Table 3: Annual Income Change from the Previous Year (Employee Reported)

Method of Estimation: Multi-Nominal Logit

Dependent Variables: Increased, Frozen (Base Category), Declined

\begin{tabular}{|c|c|c|c|c|}
\hline & (1) & (2) & (3) & (4) \\
\hline Dependent Variable & Increased & Decreased & Increased & Decreased \\
\hline \multirow[t]{3}{*}{ Age } & -0.06 & 0.03 & -0.07 & -0.01 \\
\hline & $(0.03)$ & $(0.03)$ & $(0.03)$ & $(0.03)$ \\
\hline & {$[-0.02]$} & [0.01] & {$[-0.01]$} & {$[0.00]$} \\
\hline \multirow[t]{3}{*}{$\mathrm{Age}^{2}$} & - & - & 0.00 & 0.00 \\
\hline & & & $(<0.00)$ & $(<0.00)$ \\
\hline & & & {$[<-0.00]$} & {$[<0.00]$} \\
\hline \multirow[t]{3}{*}{ Ten } & -0.01 & 0.02 & -0.03 & 0.10 \\
\hline & $(0.03)$ & $(0.03)$ & $(0.09)$ & $(0.08)$ \\
\hline & {$[<-0.00]$} & {$[0.00]$} & {$[-0.01]$} & {$[0.01]$} \\
\hline \multirow[t]{3}{*}{$\operatorname{Ten}^{2}$} & - & - & 0.00 & -0.00 \\
\hline & & & $(<0.00)$ & $(<0.00)$ \\
\hline & & & {$[<0.00]$} & {$[<0.00]$} \\
\hline \multirow[t]{2}{*}{ High School } & -0.11 & -0.40 & -0.06 & -0.35 \\
\hline & $(0.41)$ & $(0.30)$ & $(0.44)$ & $(0.29)$ \\
\hline \multirow[t]{2}{*}{ Tech. Coll. } & 1.95 & 2.05 & 1.97 & 2.12 \\
\hline & (1.26) & (1.15) & (1.26) & (1.17) \\
\hline \multirow[t]{2}{*}{ Firm Tech. } & 0.29 & 0.46 & 0.33 & 0.51 \\
\hline & $(0.46)$ & $(0.31)$ & $(0.48)$ & $(0.33)$ \\
\hline \multirow[t]{2}{*}{ Junior Coll. } & 1.12 & 0.33 & 1.17 & 0.43 \\
\hline & $(0.76)$ & $(0.71)$ & $(0.74)$ & $(0.70)$ \\
\hline \multirow[t]{2}{*}{ Coll. (BA) } & -0.19 & -0.89 & -0.14 & -0.69 \\
\hline & $(0.67)$ & $(0.50)$ & $(0.71)$ & $(0.50)$ \\
\hline \multirow[t]{2}{*}{ College (BS) } & -0.10 & -0.26 & -0.06 & -0.12 \\
\hline & (0.59) & $(0.40)$ & $(0.61)$ & $(0.44)$ \\
\hline \multirow[t]{2}{*}{ Grad. School } & -0.08 & -1.20 & -0.08 & -1.02 \\
\hline & $(0.61)$ & (0.59) & $(0.64)$ & $(0.67)$ \\
\hline Income, Industry, Occupation, Dummies & Yes & Yes & Yes & Yes \\
\hline Observations & \multicolumn{2}{|c|}{1557} & \multicolumn{2}{|c|}{1557} \\
\hline
\end{tabular}

Note: Firm-level clustering, robust standard errors are reported in parentheses. Marginal effects evaluated at the sample mean are in brackets. 
Table 4: OLS and Firm-level Fixed Effects Estimation of Satisfaction Determination

Dependent Variable: Satisfaction with Current Annual Income

$($ Expressed in Percentage: Mean $=70.93)$

\begin{tabular}{|c|c|c|c|c|c|c|c|}
\hline & (1) & (2) & (3) & (4) & (5) & (6) & (7) \\
\hline \multirow{2}{*}{ Income Increase } & 8.04 & 6.62 & 7.35 & 4.53 & 5.11 & 5.34 & 5.25 \\
\hline & $(1.18)$ & (1.13) & $(1.21)$ & $(1.13)$ & $(1.30)$ & (1.08) & $(1.07)$ \\
\hline \multirow{2}{*}{$\begin{array}{l}\text { Income Increase } \\
* \text { Age-Mean(Age) }\end{array}$} & - & - & - & - & - & -0.34 & -0.32 \\
\hline & & & & & & $(0.11)$ & $(0.14)$ \\
\hline \multirow[t]{2}{*}{ Inc. Decline } & -3.13 & -3.45 & -2.26 & -2.96 & -2.14 & -2.32 & -2.20 \\
\hline & $(1.35)$ & $(1.25)$ & $(1.18)$ & $(1.10)$ & $(1.08)$ & $(1.01)$ & $(1.39)$ \\
\hline \multirow{2}{*}{$\begin{array}{l}\text { Inc. Decline } \\
* \text { Age-Mean(Age) }\end{array}$} & - & - & - & - & - & -0.00 & 0.02 \\
\hline & & & & & & $(0.18)$ & $(0.17)$ \\
\hline \multirow[t]{2}{*}{ Age } & -0.14 & 0.02 & -0.10 & 0.23 & 0.12 & 0.28 & 0.23 \\
\hline & $(0.25)$ & $(0.27)$ & $(0.25)$ & $(0.28)$ & $(0.25)$ & $(0.21)$ & $(0.21)$ \\
\hline \multirow[t]{2}{*}{ Ten } & 0.18 & 0.12 & 0.27 & 0.06 & 0.19 & 0.19 & 0.29 \\
\hline & $(0.22)$ & $(0.24)$ & $(0.22)$ & $(0.23)$ & $(0.20)$ & $(0.19)$ & $(0.19)$ \\
\hline Education Dummies & Yes & Yes & Yes & Yes & Yes & Yes & Yes \\
\hline Income Dummies & Yes & Yes & Yes & Yes & Yes & Yes & Yes \\
\hline Ind. Occupation. Dummies & Yes & Yes & Yes & Yes & Yes & Yes & Yes \\
\hline Relative Inc. & No & Yes & Yes & Yes & Yes & Yes & Yes \\
\hline Trust in Firm & No & No & No & Yes & Yes & Yes & Yes \\
\hline Firm Growth & No & No & Yes & No & Yes & Yes & Yes \\
\hline Firm Fixed Effects & No & No & No & No & No & No & Yes \\
\hline Observations & 1552 & 1552 & 1457 & 1524 & 1432 & 1432 & 1432 \\
\hline R-squared & 0.22 & 0.26 & 0.28 & 0.39 & 0.40 & 0.40 & - \\
\hline
\end{tabular}

Note: Firm-level clustering, robust standard errors are reported in parentheses for the OLS estimates.

Usual standard errors are in parentheses for the fixed effects estimates. 
Table 5: Ordered Probit Estimation of the Determination of the Change of Workers' Morale Dependent Variable: The Change of Individual Works' Morale from 3 Years Ago

(1: Declined, 2: Rather Declined, 3: Hard to Tell, 4: Rather Increased, 5: Increased; Mean = 3.11)

\begin{tabular}{|c|c|c|c|c|c|c|c|}
\hline & $(1)$ & (2) & (3) & (4) & (5) & (6) & (7) \\
\hline \multirow{2}{*}{ Income Increase } & 0.19 & 0.14 & 0.12 & -0.01 & -0.02 & -0.01 & -0.01 \\
\hline & $(0.07)$ & $(0.07)$ & $(0.07)$ & $(0.09)$ & (0.09) & $(0.10)$ & $(0.11)$ \\
\hline \multirow{2}{*}{$\begin{array}{l}\text { Income Increase } \\
* \text { Age-Mean(Age) }\end{array}$} & - & - & - & - & - & 0.00 & -0.00 \\
\hline & & & & & & $(0.01)$ & $(0.01)$ \\
\hline \multirow[t]{2}{*}{ Inc. Decline } & -0.20 & -0.22 & -0.23 & -0.15 & -0.18 & -0.16 & -0.15 \\
\hline & $(0.07)$ & $(0.07)$ & $(0.07)$ & $(0.07)$ & $(0.07)$ & $(0.08)$ & $(0.09)$ \\
\hline \multirow{2}{*}{$\begin{array}{l}\text { Inc. Decline } \\
* \text { Age-Mean(Age) }\end{array}$} & - & - & - & - & - & -0.01 & -0.01 \\
\hline & & & & & & $(0.01)$ & $(0.01)$ \\
\hline \multirow[t]{2}{*}{ Age } & -0.02 & -0.01 & -0.01 & -0.01 & -0.01 & -0.01 & -0.01 \\
\hline & $(0.01)$ & $(0.01)$ & $(0.01)$ & $(0.01)$ & $(0.01)$ & $(0.01)$ & $(0.01)$ \\
\hline \multirow[t]{2}{*}{ Ten } & -0.00 & -0.01 & -0.01 & -0.01 & -0.01 & -0.01 & -0.01 \\
\hline & $(0.01)$ & $(0.01)$ & $(0.01)$ & $(0.01)$ & $(0.01)$ & $(0.01)$ & $(0.01)$ \\
\hline \multirow[t]{2}{*}{ Cut Point 1} & -2.56 & -2.32 & -2.89 & -2.59 & -2.81 & -2.75 & -2.04 \\
\hline & $(0.51)$ & $(0.54)$ & $(0.51)$ & $(0.50)$ & $(0.50)$ & $(0.47)$ & $(0.52)$ \\
\hline \multirow[t]{2}{*}{ Cut Point 2} & -1.62 & -1.37 & -1.92 & -1.41 & -1.63 & -1.57 & -0.82 \\
\hline & $(0.52)$ & $(0.54)$ & $(0.50)$ & $(0.51)$ & $(0.50)$ & $(0.45)$ & $(0.52)$ \\
\hline \multirow[t]{2}{*}{ Cut Point 3} & -0.63 & -0.37 & -0.89 & -0.25 & -0.43 & -0.37 & 0.40 \\
\hline & $(0.51)$ & $(0.53)$ & $(0.49)$ & $(0.50)$ & $(0.49)$ & $(0.44)$ & $(0.51)$ \\
\hline \multirow[t]{2}{*}{ Cut Point 4} & 0.69 & 0.97 & 0.48 & 1.30 & 1.15 & 1.21 & 2.00 \\
\hline & $(0.51)$ & $(0.53)$ & $(0.49)$ & $(0.50)$ & $(0.47)$ & $(0.42)$ & $(0.47)$ \\
\hline Educ. Dummies & Yes & Yes & Yes & Yes & Yes & Yes & Yes \\
\hline Income Dummies & Yes & Yes & Yes & Yes & Yes & Yes & Yes \\
\hline Ind. Occ. Dum & Yes & Yes & Yes & Yes & Yes & Yes & Yes \\
\hline Relative Inc. & No & Yes & Yes & Yes & Yes & Yes & Yes \\
\hline Trust in Firm & No & No & No & Yes & Yes & Yes & Yes \\
\hline Firm Growth & No & No & Yes & No & Yes & Yes & Yes \\
\hline Firm Fixed Effects & No & No & No & No & No & No & Yes \\
\hline Observations & 1553 & 1553 & 1456 & 1523 & 1430 & 1430 & 1430 \\
\hline Log Likelihood & -2100 & -2082 & -1917 & -1816 & -1681 & -1681 & -1654 \\
\hline
\end{tabular}

Note: Standard errors are in parentheses. Firm-level clustering, robust standard errors are reported in the parentheses for the specifications that do not include firm fixed effects. 
Figure1: CPI of J apan (March 2000=100)

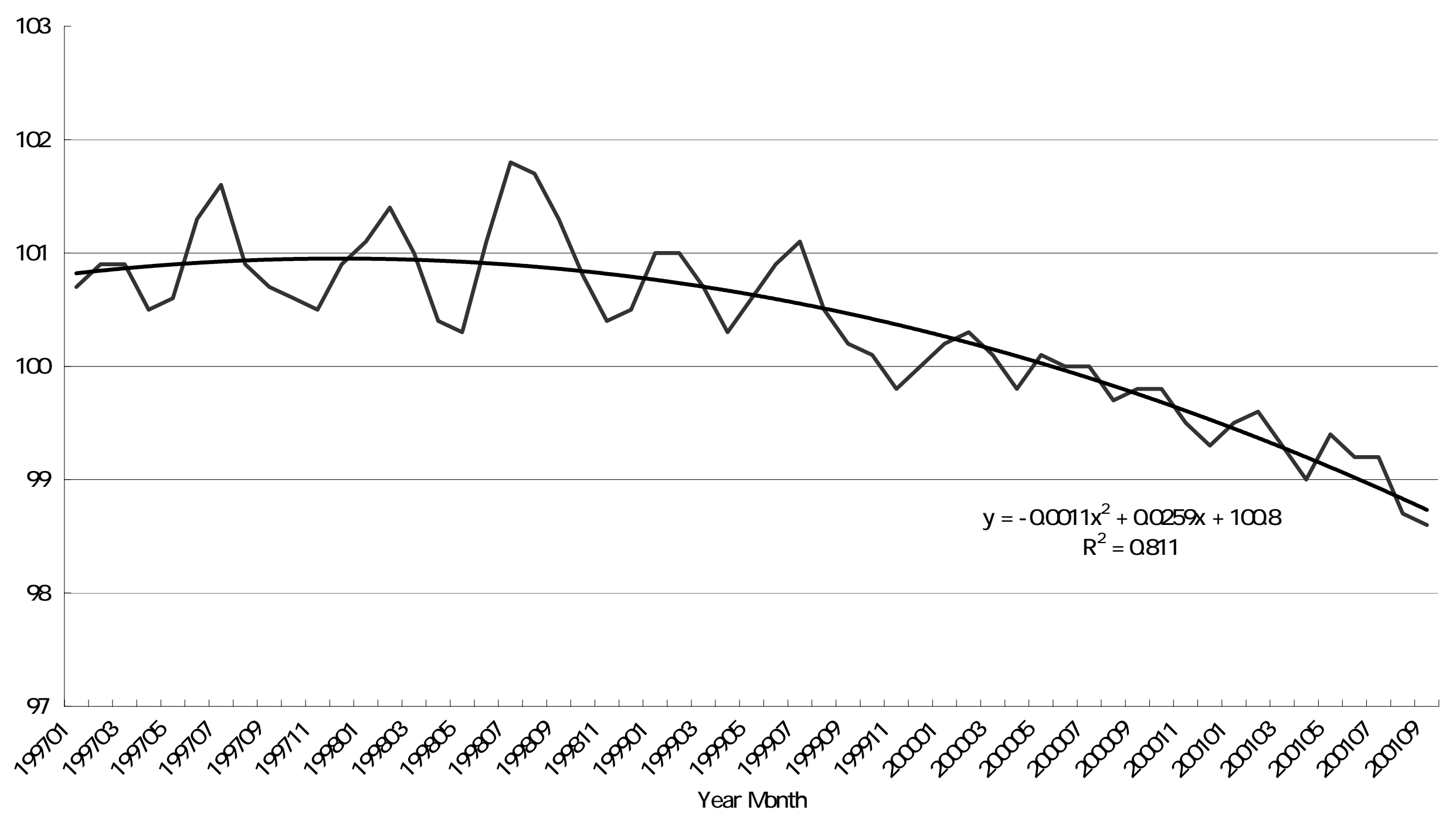

